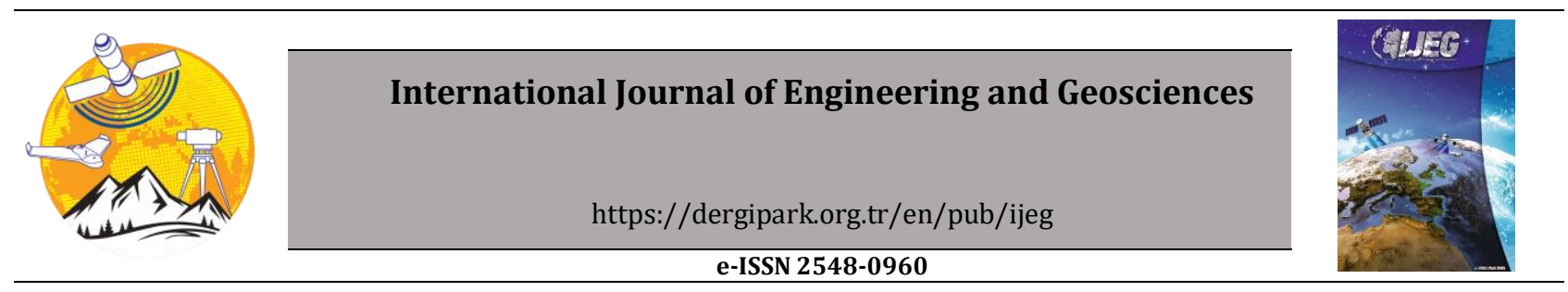

\title{
Analysis of literature on 3D cadastre
}

\author{
Fatih Döner*1 (D) \\ 1Gumushane University, Faculty of Engineering and Natural Sciences, Department of Geomatics Engineering, Gumushane, Turkey
}

\author{
Keywords \\ Cadastre \\ 3D Cadastre \\ LADM \\ Literature survey
}

\begin{abstract}
In this study, it is aimed to analyse the three-dimensional (3D) cadastre literature in terms of legal, institutional, and technical aspects. For this purpose, 441 publications published between 2001 and 2019 were examined. In the literature, which includes publications from 59 different countries the studies mostly focused on technical issues. An international consensus on legal, institutional, and technical aspects of a 3D cadastre solution seems difficult. Since rights, restrictions, and responsibilities with a 3D component are somehow registered administratively, stakeholders from the legal domain are reluctant to 3D cadastre. From a technical point of view, the technology required to use 3D digital data for registration has matured sufficiently in the past twenty years. However, further research on a real 3D cadastre solution, creating a workflow that considers both current legal and technical framework beyond pilot studies, is needed.
\end{abstract}

\section{INTRODUCTION}

The substantial increase in the world population in the past two centuries has led to intensification of land use, especially in urban areas. This increasing trend in the population has gradually altered the relationship between the land and the people, increasing the importance of land ownership (Ting and Williamson 1999). Accordingly, a system was required to record the ownership of the property in a clear and undisputable way. Although various names (land information system, land recording, land administration, etc.) are used to describe this system, it is now called cadastre (FIG 1995; Dale and Mclaughlin 1999; Steudler et al. 2004). From a conceptual point of view, one of the foundations of the cadastre is that there can be no gaps or overlaps in the parcelation on which the rights are based, that is, a planar partition of the surface. The same foundation (a partition of space with no overlaps or gaps) is also the basis of the conceptual thinking with respect to $3 \mathrm{D}$ cadastre (Stoter 2004; Döner et al. 2008). In other words, 3D cadastre is a cadastre that registers and represents the space where rights (also the restrictions and responsibilities) applied (Döner 2010). Reflection of this conceptual definition can be seen in logo of International Federation of Surveyors (FIG) Working Group on 3D Cadastres in Figure 1.

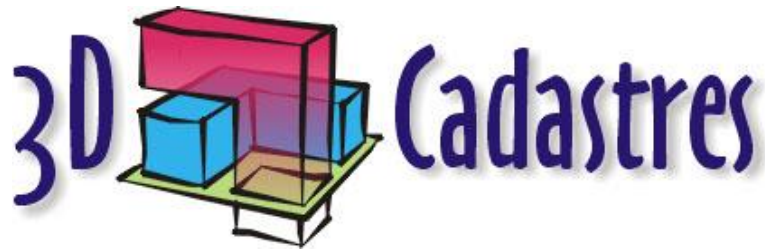

Figure 1. Logo of FIG working group on 3D cadastres

Numerous studies have been conducted to compare and classify the researches focused on cadastre and land administration. Çağdaş and Stubkjær (2009) analysed selected PhD theses written in English about cadastre in terms of methodology, concepts, and methods. Paulsson and Paasch (2015) conducted a literature review for the LADM (Land Administration Domain Model, ISO 19152), which was accepted as an ISO standard in 2012. Oosterom (2013) evaluated the activities of the FIG Working Group on 3D Cadastres. Paulsson and Paasch (2013) discussed the publications
${ }^{*}$ Corresponding Author
${ }^{*}$ (fatihdoner@gumushane.edu.tr) ORCID ID 0000 - 0002 - 3620 - 5687
Cite this article

Doner F (2021). Analysis of literature on 3D cadastre. International Journal of Engineering and Geosciences, 6(2), 90-97 
written in English between 2001 and 2011 on the concept of $3 \mathrm{D}$ property in terms of their legal aspects.

The first international discussion about the 3D cadastre subject took place in 2001 at the workshop entitled 3D Cadastres, under the seventh commission of the FIG. At the 24th FIG congress held in Sydney in April 2010, it was decided to reestablish a working group called '3D Cadastre' in order to make further progress on 3D cadastre research. The main purpose of the working group is to create a functioning structure for 3D cadastre. For this structure, two main goals were determined. The first is to follow a common concept and terminology. For this purpose, the use of ISO 19152 LADM has been adopted. Secondly, common levels for 3D cadastre applications were determined as legal, organisational and technical. Thus, it will be possible to compare different ideas and applications more easily (Döner et al. 2011; van Oosterom et al. 2014). In the past twenty years, many scientific meetings, academic studies, and pilot projects (Cemellini et al. 2020; Larsson et al. 2020; Vandysheva et al. 2011; Ying et al. 2012; Guo et al. 2011) have been performed on 3D cadastre. Nevertheless, during that period, there have been significant changes in the visualization of 3D data, data collection techniques, the usability of BIM (Building Information Modelling) data (Ying et al. 2017; Thompson et al. 2017; Atazadeh et al. 2017), as well as in policies and institutional structures. The effects of the changes on 3D cadastre research have not been extensively studied so far. Therefore, in this study, the 3D cadastre literature was analysed, and the trends and challenges in research and applications were investigated in terms of legal, institutional, and technical aspects. For this analysis, the approach of analysing the publications published in English between 2001 and 2019 under the FIG Working Group on 3D Cadastres was adopted. In the second section, the publications used for analysis and the approach in the classification of these publications are introduced. Findings of the analysed 3D cadastre publications are presented in the third section. Then, challenges and trends in 3D cadastre research are evaluated in three groups under the fourth section. Finally, the study ends with conclusions in section 5 .

\section{MATERIALS and METHODS}

Quantitative analysis of certain characteristics of scientific documents is defined as bibliometric analysis (Schloegl and Gorraiz 2006). This analysis aims to determine the priority areas and development direction by examining the publications in a specific journal or publications related to a specific subject (Motoyama and Eisler 2011; Alcantara and Martens 2019). While the analysis is performed, answers are sought to questions such as what types the publications are, what the most frequently used keywords are, how the number of publications is distributed by years, the number of authors of the publications, and at which institutions the authors work (Biljecki 2016; De Bakker et al. 2005; Garnett et al. 2013).

The methodological basis of this study is the analysis of 3D cadastre publications. For this purpose, 3D cadastre publications will first be classified into categories; then the trends in each class will be determined. Since it is not possible to capture all 3D cadastre literature that exists, selection of most relevant publications is an important part of the methodology. Therefore, the publications to be examined in the study were determined to be those published in the FIG Working Group on 3D Cadastres web page ${ }^{1}$ between 2001 and 2019. The reason why year 2001 was chosen as the beginning is that it was the first time that $3 \mathrm{D}$ cadastre was discussed at an international meeting. The publications on the FIG website are intended for international audiences and therefore are published in English. That prevents the classification of studies related to specific countries and written in languages other than English. Publications in languages other than English are excluded from the scope of this article.

In this study, three classes were identified in the classification of publications in 3D cadastre literature. These are legal, institutional and technical classes. This classification approach for 3D cadastre was actually adopted in the first 3D Cadastre Workshop in 2001. In the second 3D Cadastre Workshop held in 2011, four classes were proposed to classify and compare 3D cadastre studies. Those are registration of 3D parcels, 3D data management, $3 \mathrm{D}$ visualization, and sharing of 3D parcels. When the two approaches are considered together for classification, it is understood that the registration of 3D parcels in the second approach coincides with the legal class in the first approach, that the 3D visualization class in the second approach corresponds to the technical class in the first approach, and that the sharing of 3D parcels in the first approach can be described with the institutional class in the first approach. Therefore, in this article, 3D cadastre literature has been classified and analysed in the three classes of legal, institutional, and technical due to the simpler structure.

When 3D cadastre publications are analysed, it is seen that some publications can fit into two of the classes identified in this study (legal and institutional, legal and technical, or institutional and technical) or into all three classes at the same time. In such cases, the approach of usage of primary and secondary classes as applied in Paulsson and Paasch (2015) was adopted to determine the class of the publication. The primary and secondary classes describe the dominant class and the less dominant

${ }^{1}$ www.gdmc.nl/3dcadastres/literature/ (accessed December 19th, 2019). 
class or classes, respectively. The number of publications in the secondary class is expressed in parentheses.

\section{FINDINGS}

The distribution of the analysed 3D cadastre publications according to the classes are presented in this section together with statistical findings.

\subsection{Distribution of Publications According to Classes}

The distribution of the examined 441 publications on 3D cadastre, according to the three identified classes, is shown in Table 1. Because 7 of the 441 publications were prefaces for books, journals, or workshops, they were excluded from the evaluation. As a result, the total number of publications reviewed was 434. Of the 434 publications, 154 were classified as legal, 54 were classified as institutional, and 226 were classified as technical. The year in which the most publications were made was 2018, with 65 publications. As of December 2019, publications of 2019 have not yet been added to the FIG Working Group on 3D Cadastres Literature page. Therefore, proceedings of FIG Working Week 2019 and 8th LADM Workshop 2019 were examined for 2019.

\subsection{Statistical Findings}

The graph in Figure 2 shows the distribution of the publications examined by years. Because 2011, $2012,2014,2016$, and 2018 were the years in which 3D cadastre workshops were held, the number of publications in those years was higher than in the other years. Also, the book Best Practices 3D Cadastres was published by the FIG in 2018, and, in the same year, the special edition of the ISPRS International Journal of Geo-Information on 3D cadastre was published. In the period of 2001-2019, the average annual number of publications for the first ten years was 10.4, while the average annual number of publications for the last nine years was 36.7. Overall, the average annual number of publications was 22.8 .

The graph in Figure 3 shows the distribution of the examined publications by publication types. Of the 434 publications, 352 consist of proceedings, and 63 of them are articles. In addition, there are four $\mathrm{PhD}$ dissertations and one master's thesis in the literature (given in the FIG 3D Cadastres Working Group Literature page in English). The first PhD dissertation was completed in 2004. In that study, the cadastral framework in the Netherlands was examined, and alternatives for the implementation of 3D cadastre were presented (Stoter 2004). The second PhD study was completed in 2007 in Sweden. That study focused on legal issues and explained the facilities and restrictions for establishing a 3D property system (Paulsson 2007). The third PhD dissertation was completed in 2014 in Australia. In that study, user needs had been determined and a web-based prototype developed and tested for 3D representation of cadastral data (Davood 2014). In the fourth PhD dissertation, completed in Canada in 2015, a technical study was carried out for 3D modelling of individual units (Wang 2015). The main journals in which articles are published are Computers, Environment and Urban Systems (20 articles), ISPRS Int. J. Geo-Inf. (20 articles), Land Use Policy (5 articles) and Geodetski Vestnik (4 articles). Furthermore, 183 papers are presented in 3D Cadastre Workshops, 83 papers are presented in FIG Working Weeks, 43 papers are presented in FIG Congresses and 6 papers are presented in LADM Workshops.

Table 1. Distribution of 3D cadastre publications ( ) = secondary class

\begin{tabular}{lllll}
\hline Year & Legal & Institutional & Technical & Total/Year \\
\hline 2001 & $15(1)$ & $5(3)$ & $9(0)$ & $29(4)$ \\
2002 & $3(0)$ & $1(1)$ & $4(0)$ & $8(1)$ \\
2003 & $7(0)$ & $2(3)$ & $7(1)$ & $16(4)$ \\
2004 & $2(3)$ & $1(0)$ & $6(0)$ & $9(3)$ \\
2005 & $1(1)$ & $1(0)$ & $8(0)$ & $10(1)$ \\
2006 & $4(1)$ & $0(1)$ & $5(0)$ & $9(2)$ \\
2007 & $1(0)$ & $0(0)$ & $1(0)$ & $2(0)$ \\
2008 & $3(0)$ & $0(1)$ & $1(0)$ & $4(1)$ \\
2009 & $2(0)$ & $1(0)$ & $3(0)$ & $6(0)$ \\
2010 & $3(1)$ & $2(2)$ & $6(0)$ & $11(3)$ \\
2011 & $16(0)$ & $6(7)$ & $25(0)$ & $47(7)$ \\
2012 & $20(1)$ & $2(7)$ & $21(1)$ & $43(9)$ \\
2013 & $4(0)$ & $7(0)$ & $7(1)$ & $18(1)$ \\
2014 & $10(3)$ & $5(6)$ & $27(0)$ & $42(9)$ \\
2015 & $12(1)$ & $3(2)$ & $11(1)$ & $26(4)$ \\
2016 & $13(0)$ & $5(3)$ & $22(1)$ & $40(4)$ \\
2017 & $12(3)$ & $4(5)$ & $20(0)$ & $36(8)$ \\
2018 & $23(4)$ & $8(7)$ & $34(4)$ & $65(15)$ \\
2019 & $3(1)$ & $1(0)$ & $9(4)$ & $13(5)$ \\
Total & $154(20)$ & $54(48)$ & $226(13)$ & $434(81)$ \\
\hline & & & &
\end{tabular}

The graph in Figure 4 shows the distribution of the 434 publications examined by the number of authors. A total of 104 publications have been published by one author, 106 publications have two authors, and 86 publications have three authors. A total of 13 publications have more than eight authors.

The graph in Figure 5 was prepared to determine the countries in which the most studies on 3D cadastre have been performed. The country of the authors' residence or institution was taken into consideration. Accordingly, 120 of the 434 publications published in 2001-2019 have at least one Dutch author. That is followed by Australia, with 58 publications. Among the publications of authors from 59 different countries, the number of 
publications by Dutch authors is especially striking. In addition, it is noteworthy that the names of the persons who are actively involved in the organization of conferences or workshops and who are responsible for the updating of web pages appear as authors in many of the publications.

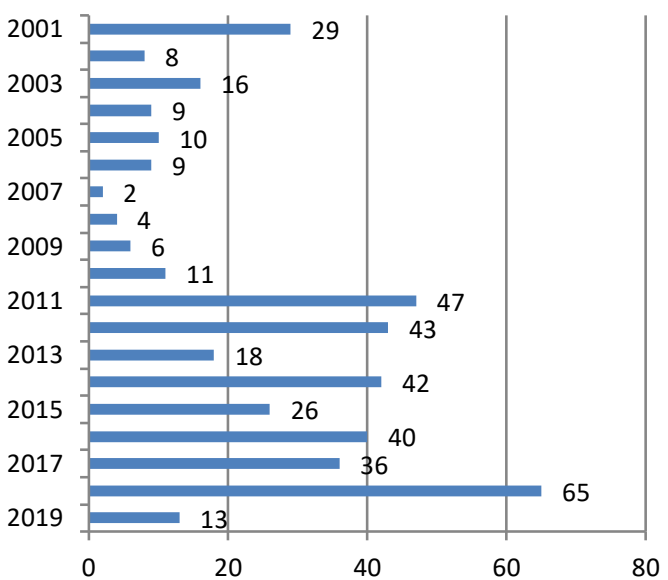

Figure 2. Distribution of 3D cadastre publications by years

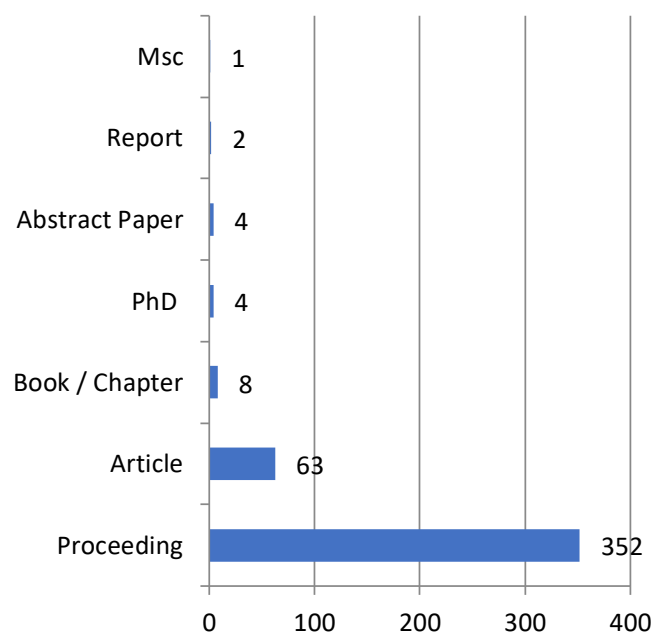

Figure 3. Distribution of 3D cadastre publications by publication types

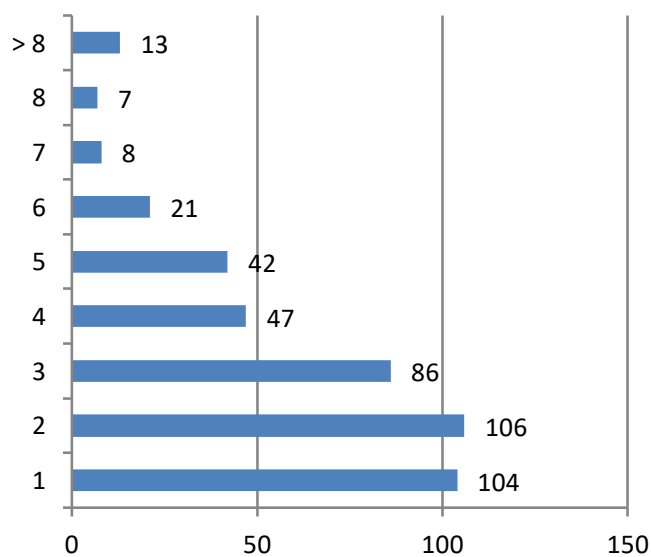

Figure 4. Distribution of 3D cadastre publications by number of authors

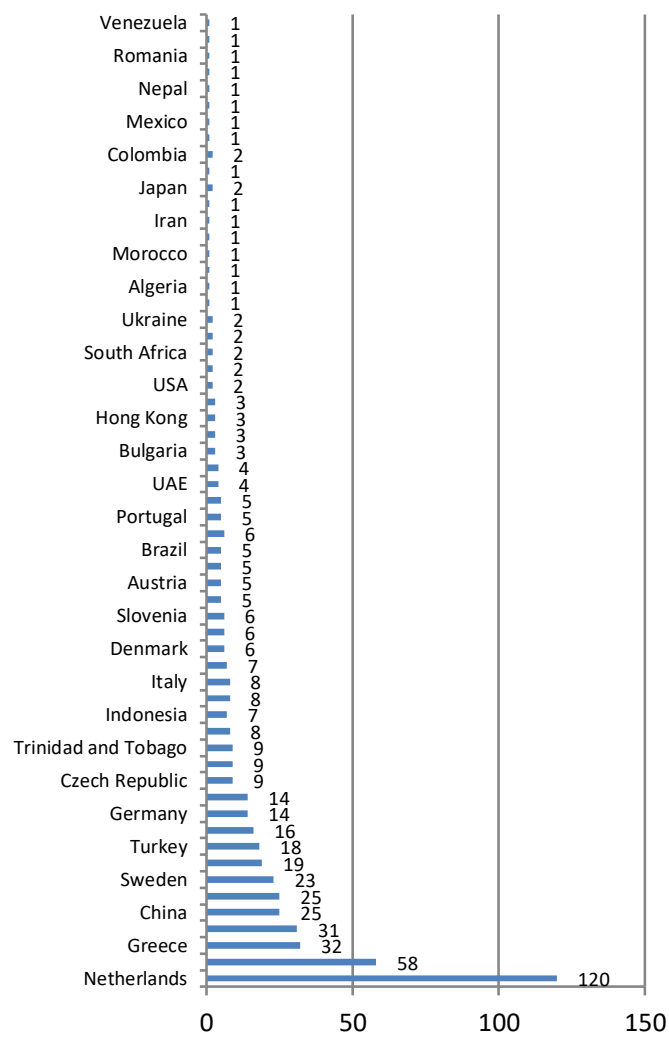

Figure 5. Distribution of 3D cadastre publications by country of authors

\section{DISCUSSION and FUTURE STUDIES}

For a 3D cadastre to be realised in real terms, three stages of development should be considered together. They can be designated as legal, institutional and technical stages (Lemmen and van Oosterom 2003). If legal definition of 3D properties is not available, it would be meaningless to survey and register 3D objects and rights (Kitsakis and Dimopoulou 2014). Therefore, the first stage begins with the definition of laws that will legally allow the registration of 3D property units.

Necessary arrangements and workflow for registration of legally defined 3D property units are considered in the institutional stage (Molen 2003). What information is needed for registration and how it will be structured, registered, stored, and presented are addressed at the institutional stage. Finally, in the technical stage, 3D spatial information of the property units is integrated with the existing cadastre (Guo et al. 2013).

When the 3D cadastre literature was analysed, it was observed that some legal and institutional arrangements, as well as technical studies, have been performed to enable the establishment of 3D property units in several countries. In this section of the study, 3D cadastre studies were evaluated with regard to legal, institutional and technical aspects.

\subsection{Legal Aspects}

As in 2D cadastre, the legal basis is the foundation of 3D cadastre. The legal aspect supports 
the registration of 3D property in 3D cadastre. It was observed that the number of publications evaluated in the legal class after 2010 more than doubled when compared to the period before 2010. Despite that increase, publications in the legal class consisted of only one third of the total publications, and the number of publications dealing with purely legal aspects of 3D cadastre was quite small. In the publications considered to be of legal class, the existing legal framework in the country is explained mostly in terms of defining boundaries of property rights on land, establishing individual units and limited real rights. After the introductory explanations, the researchers present technical solutions for a 3D cadastre in their publications. However, they do not mention about availability of the legal regulations required for the implementation of these solutions.

On the other hand, legal regulations in some countries are noteworthy in the publications reviewed. For instance, legal arrangements have been made to improve the registration of individual units in Scandinavian countries (Larsson et al. 2018; Shnaidman et al. 2019) and, in the Netherlands, legal arrangements have been made to include 3D digital information on utilities and complex buildings in the title deed (Stoter et al. 2017). In addition, it is legally possible to establish vertically bounded property units in some states of Australia (Shojaei et al. 2017) and Canada (Pouliot et al. 2016). Those 3D property units are called volumetric parcels in Australia, while they are called air-space parcels in Canada. In Turkey, an amendment to the Expropriation Act has been ratified so that the property of space required for utilities over or under the parcel in question can be separated from the parcel property without expropriating it when required conditions are satisfied (OG, 2014).

\subsection{Institutional Aspects}

Cadastral systems only make sense if they exist within an institutional framework. The institutional aspect of the 3D cadastre therefore includes the duties and responsibilities of the public registration and mapping institutions for 3D registration (van Oosterom 2013). At this stage of the study, it is preferred to use the word institutional together with the word organisational. This is because, in some publications, the word organisational, which is more comprehensive, was used instead of institutional.

The institutional/organisational aspect of the 3D cadastre includes the authority and responsibilities in production, management, updating, and distribution of the 3D data as well as the workflow required to realize the 3D cadastre. The number of publications in the institutional/ organisational class is approximately $1 / 8$ of the total publications, and it is the class with the least number of publications of all classes.

The fact that the number of publications in the institutional/organisational class is less than that of the publications in the technical class can be explained by a few reasons. Firstly, the cost of establishing a 3D cadastre is more prominent than its benefits. In terms of the institutional aspect, it is difficult to identify the economic benefits of better registration and representation of legal situation. As a result, it is hard to study the efficiency (cost, time, and compliance ratios) and the measurement of impact (cost-benefit analysis) in the institutional/organisational aspect.

Secondly, in many publications proposing solutions to the technical issues of 3D cadastre, researchers assume that the legal and institutional framework required for implementing the proposed solution is already present. However, cadastral institutions have structures with absolute procedures based on robust legal foundations. The legal task of the cadastre and land registry is to register the boundaries of real estate and to provide information on the legal status on the real estate. When performing that task, institutions prefer themselves keep away from 3D cadastre due to uncertainties such as defining 3D property boundaries even though 3D modelling and representation possibilities improved. In many countries especially where registration is under state guarantee, there is a view that complexities caused by changes on legal and institutional framework for 3D cadastre would exceed the benefit of 3D cadastre. As a result, for employees of institutions responsible for the legal affairs of the land registration, such as lawyers and notaries, remaining at a familiar area is more appealing.

\subsection{Technical Aspects}

As expected, in the 3D cadastre publications analysed, the largest number of publications falls into the technical class. About half of all publications are in the technical class. In the past two decades, technologies for collecting, storing, presenting, and visualizing 3D data have developed sufficiently. Furthermore, the relationship between the 3D models of the physical world and legal entities has become more visible, thanks to new 3D data collection techniques and BIM models.

The main research topics of the technical class publications are spatial data infrastructures, data modelling, database management, geographic information systems, visualization and geometric representation, cadastral surveying, topology, data exchange formats, and LADM.

In the decade after 2001, which was accepted as the starting point for 3D cadastre research, technical studies were mainly about modelling 3D cadastral data in Database Management System (DBMS), accessing and querying 3D cadastral data by using Computer Aided Design (CAD) and Geographic Information Systems (GIS) tools (Döner and Biyik 2011; Baz and Geymen, 2006), and preparing the selected data for the cases of 3D situations. 
After the adoption of LADM as an ISO standard (ISO 19152) in 2012, it was observed that, in many countries, the conceptual scheme of LADM was used for 3D cadastre designs and country profiles were prepared (Lee et al. 2015; Janečka and Souček 2017; Felus et al. 2014; Radulović et al. 2017). In the last five-year-period, on the other hand, studies for modelling 3D information of individual units by using GML-based (CityGML, IndoorGML) and IFCbased (BIM) spatial data models are more dominant. In addition, it was observed that some 3D cadastre research and applications are supported in projects under the subheadings of Smart Cities and Digital Twins within the scope of European Union Horizon 2020 grant program. These studies aim to create an infrastructure for sustainable city design, management, and planning by integrating digital 3D property information with data such as noise, energy, air pollution, mobility, and temperature (Stoter et al. 2019).

From legal point of view, although there are laws pertaining to the use of the vertical dimension of property in each country, there is no internationally recognized definition of a 3D property. In some publications, 3D property refers to a volumetrically restricted property, while in others, the word space is used to refer to a larger unit that includes several real estate or utilities. When the legal-class publications were examined, it was understood that there are problems in translating legal terms into English. Sometimes different authors from the same country would use different expressions to translate the same terms into English. Therefore, a common terminology should be used to provide further progress in legal aspect.

From organisational point of view, the benefits of 3D cadastre to the organisation and users, whether those benefits are outweighed by the costs in the short or long term, should be investigated when implementation of 3D cadastre is considered. Comparative studies with a greater number of participants from different countries are needed to recognize different legal and institutional framework and to learn their strengths in the implementation of 3D cadastre.

From technical point of view, developments in 3D geo-information sciences can now be regarded as evidence that the demand for the use of 3D information has increased to the extent that it cannot be confined to legal purposes alone. Therefore, 3D cadastre will need to be evaluated from a wider perspective in the future. Further technical issues to be addressed in the future can be listed as revision of LADM, integration of 3D physical and legal objects, four-dimensional 4D cadastre, and more advanced visualization (augmented reality and virtual reality).

\section{CONCLUSION}

The inadequacy of the existing cadastral systems in registering and representing of some situations that emerge in the modern world has led to an increase in interest and research in 3D cadastre along with the effect of developing technology in the last twenty years. In this article, 441 publications from 59 different countries published between 2001 and 2019 were classified and analysed to point out legal, institutional, and technical trends and challenges in 3D cadastre research. According to the results of the analysis, it is seen that there have been significant changes in the twenty-year period since the start of 3D cadastre research and that these changes have partly changed the scope of the 3D cadastre. Nowadays, the 3D cadastre should be considered from a wider perspective by accepting that 3D property information is only one of the information type needs to create the infrastructure for management of cities. The interest of legal and institutional stakeholders to 3D cadastre tends to decrease due to uncertainties in defining property boundaries in 3D and lack of legal regulation. Therefore, further research on a real 3D cadastre solution, creating a workflow that considers both current legal and technical framework beyond pilot studies, is needed. Potential future research areas for researchers to consider in a 3D cadastre research are the revision of LADM, the use of digital data models in cadastre, institutional arrangements for dissemination of 3D cadastral data via spatial data infrastructures and integration of legal and physical 3D objects in cadastre.

\section{REFERENCES}

Alcantara D P \& Martens (2019). Technology road mapping (TRM): a systematic review of the literature focusing on models. Technological Forecasting and Social Change, 138, 127-138. DOI: 10.1016/j.techfore.2018.08.014

Atazadeh B, Kalantari M, Rajabifard A \& Ho S (2017). Modelling building ownership boundaries within BIM environment: A case study in Victoria, Australia. Computers, Environment and Urban Systems, 61, 24-38. DOI: 10.1016/j.compenvurbsys.2016.09.001

Baz İ \& Geymen A (2006). Automatic document preparation by interacting GIS software packages using office programs. Advances in Engineering Software, 37(11), 763-769. DOI: 10.1016/j.advengsoft.2006.04.004

Biljecki F (2016). A scientometric analysis of selected GIScience journals. International Journal of Geographical Information Science, 30(7), 13021335. DOI: $10.1080 / 13658816.2015 .1130831$

Çağdaş V \& Stubkjær E (2009). Doctoral research on cadastral development. Land Use Policy, 26(4), 869-889.DOI: 10.1016/j.landusepol.2008.10.012

Cemellini B, van Oosterom P, Thompson R \& deVries $M$ (2020). Design, development and usability testing of an LADM compliant 3D Cadastral prototype system. Land Use Policy DOI: 10.1016/j.landusepol.2019.104418 
Dale P \& Mclaughlin J (1999). Land Administration. New York: Oxford University Press. ISBN 0198233906

Davood S (2014). 3D cadastral visualisation: understanding users' requirements. PhD Thesis, University of Melbourne, Australia.

De Bakker F G A, Groenewegen P \& Den Hond F. (2005). A bibliometric analysis of 30 years of research and theory on corporate social responsibility and corporate social performance. Business \& Society, 44 (3), 283317. DOI: $10.1177 / 0007650305278086$

Döner F \& Biyik C (2011). Modelling and mapping third dimension in a spatial database. International Journal of Digital Earth, 4(6), 505520. DOI: $10.1080 / 17538947.2011 .571723$

Döner F (2010). A 3D Approach for Turkish Cadastral System, PhD Thesis, Karadeniz Technical University, Turkey. (in Turkish)

Döner F, Bıyık C \& Demir O (2011). Three Dimensional Cadastre Applications in the World. Hkm - Jeodezi, Jeoinformasyon ve Arazi Yönetimi Dergisi, 2011(2), 53-59. (in Turkish).

Döner F, Thompson R, Stoter J, Lemmen C, Ploeger H \& van Oosterom P (2008). 4D land administration solutions in the context of the spatial information infrastructure. FIG Working Week 2008, Stockholm, Sweden.

Felus Y, Barzani S, Caine A, Blumkine N \& van Oosterom P (2014). Steps towards 3D Cadastre and ISO 19152 (LADM) in Israel. 4th International Workshop on 3D Cadastres, Dubai, United Arab Emirates.

FIG (1995). The FIG Statement on the Cadastre, FIG Publication No: 11.

Garnett A, Lee G \& Illes J (2013). Publication trends in neuroimaging of minimally conscious states. Peer J, 1(4).

Guo R, Li L, He B, Luo P, Ying S, Zhao Z \& Jiang R (2011). 3D cadastre in China: A case study in Shenzhen city, 2nd International Workshop on 3D Cadastres, Delft, the Netherlands, 291-307.

Guo R, Li L, Ying S, Luo P, He B \& Jiang R (2013). Developing a 3D cadastre for the administration of urban land use: A case study of Shenzhen, China. Computers, Environment and Urban Systems. 40, 46-55. DOI: 10.1016/j.compenvurbsys.2012.07.006

Janečka K \& Souček P (2017). A country profile of the Czech Republic based on an LADM for the Development of a 3D Cadastre. ISPRS International Journal of Geo-Information, 6(5). DOI: $10.3390 /$ ijgi6050143

Kitsakis D \& Dimopoulou E (2014). 3D cadastres: legal approaches and necessary reforms. Survey Review, 46, 322-332. DOI: 10.1179/1752270614Y.0000000119

Larsson K, Paasch J M \& Paulsson J (2020). Representation of 3D cadastral boundariesfrom analogue to digital. Land Use Policy doi:10.1016/j.landusepol.2019.104178.
Larsson K, Paasch J M, Paulsson J (2018). Conversion of $2 \mathrm{D}$ analogue cadastral boundary plans into 3D digital information - problems and challenges illustrated by a Swedish case. Proceedings of 6th International FIG 3D Cadastre Workshop, Delft, the Netherlands, 7592.

Lee B-M, Kim T-J, Kwak B-Y, Lee, Y-H \& Choi J (2015). Improvement of the Korean LADM country profile to build a 3D cadastre model. Land Use Policy 49, 660-667. DOI: 10.1016/j.landusepol.2015.10.012

Lemmen C \& van Oosterom P (2003). 3D Cadastres. Computers, Environment and Urban Systems (CEUS), 27, 337-343.

Molen P (2003). Institutional aspects of 3D cadastres. Computers, Environment and Urban Systems, 27(4), 383-394.

Motoyama Y \& Eisler M N (2011). Bibliometry and nanotechnology: A meta-analysis. Technological Forecasting and Social Change, 78(7), 11741182. DOI: $10.1016 / j . t e c h f o r e .2011 .03 .013$

OG (Official Gazette) (2014). Law on re-structure of some law and legislative decisions and rebuilding of the receivables, (in Turkish), Available at: https://www.resmigazete.gov.tr/eskiler/2014 /09/20140911M1-1.htm (Accessed Date: December 29th, 2019).

Paulsson J \& Paasch J M (2013). 3D property research from a legal perspective. Computers, Environment and Urban Systems, 40, 7-13. DOI: 10.1016/j.compenvurbsys.2012.11.004

Paulsson J \& Paasch J M (2015). The land administration domain model - A literature survey. Land Use Policy, 49, 546-551. DOI: 10.1016/j.landusepol.2015.08.008

Paulsson J (2007). 3D Property Rights- An analysis of key factors based on international experience. PhD Thesis, Royal Institute of Technology, Sweden.

Pouliot J, Hubert F, Wang C, Ellul C, Rajabifard A (2016). 3D Cadastre visualization: Recent progress and future directions. Proceedings of the 5th International FIG 3D Cadastre Workshop, 337-357.

Radulović A, Sladić D \& Govedarica M (2017). Towards 3D Cadastre in Serbia: Development of Serbian Cadastral Domain Model, ISPRS International Journal of Geo-Information, 6(10).

Schloegl C \& Gorraiz J (2006). Document delivery as a source for bibliometric analyses: The case of Subito. Journal of Information Science, 32(3), 223-237. DOI: $10.1177 / 0165551506064410$

Shnaidman A, van Oosterom P, Lemmen C, Ploeger H, Karki S \& Rahman A A (2019). Analysis of the Third FIG 3D Cadastres Questionnaire: Status in 2018 and Expectations for 2022. Proceedings of FIG Working Week 2019, Hanoi, Vietnam.

Shojaei D, Olfat H, Briffa M \& Rajabifard A (2017). 3D Digital Cadastre Journey in Victoria, Australia. ISPRS Annals of the Photogrammetry, Remote 
Sensing and Spatial Information Sciences, IV4/W5, 117-123.

Steudler D, Rajabifard A \& Williamson I P (2004). Evaluation of land administration systems. Land Use Policy, 21(4), 371-380. DOI: 10.1016/j.landusepol.2003.05.001

Stoter J (2004). 3D Cadastre, PhD Thesis, Delft University of Technology, the Netherlands.

Stoter J, Ho S \& Biljecki F (2019). Considerations for a contemporary 3D Cadastre for our times. International Archives of the Photogrammetry, Remote Sensing and Spatial Information Sciences, XLII-4/W15, 81-88.

Stoter J, Ploeger H, Roes R, van der Riet E, Biljecki F, Ledoux H, Kok D \& Kim S (2017). Registration of multi-level property rights in $3 \mathrm{D}$ in the Netherlands: Two cases and next steps in further implementation. ISPRS International Journal of Geo-Information, 6(6), 158. DOI: 10.3390/ijgi6060158

Thompson R J, van Oosterom P \& Soon K H (2017). LandXML encoding of mixed 2D and 3D survey plans with multi-level topology. ISPRS International Journal of Geo-Information, 6(6), 171. DOI: $10.3390 /$ ijgi6060171

Ting L \& Williamson I P (1999). Cadastral Trends: A Synthesis. Australian Surveyor, 44(1), 46-54. DOI: $10.1080 / 00050351.1999 .10558772$ van Oosterom P (2013). Research and development in 3D cadastres. Computers, Environment and Urban Systems, 40, 1-6. DOI: 10.1016/j.compenvurbsys.2013.01.002

van Oosterom P, Stoter J, Ploeger H, Lemmen C, Thompson R \& Karki S (2014). Initial analysis of the second FIG 3D cadastres questionnaire: status in 2014 and expectations for 2018. 4th International Workshop on 3D Cadastres, Dubai, United Arab Emirates.

Vandysheva N, Tikhonov V, van Oosterom P, Stoter J, Ploeger H, Wouters R \& Penkov V (2011). 3D cadastre modelling in Russia. FIG Working Week, Marrakech, Morocco.

Wang C (2015). 3D Visualization of Cadastre: Assessing the Suitability of Visual Variables and Enhancement Techniques in the 3D Model of Condominium Property Units. PHD Thesis, Universite Laval, Québec, Canada.

Ying S, Guo R, Li L \& He B (2012). Application of 3D GIS to 3D cadastre in urban environment. 3rd International Workshop on 3D Cadastres: Developments and Practices, Shenzhen, China.

Ying S, Guo R, Yang J, He B, Zhao Z \& Jin F (2017). 3D space shift from CityGML LoD3-based multiple building elements to a 3D volumetric object. ISPRS International Journal of Geo-Information, 6(1), 17. DOI: 10.3390/ijgi6010017

(C) Author(s) 2021.

This work is distributed under https://creativecommons.org/licenses/by-sa/4.0/ 